\title{
Development and Validation of a New Stability-Indicating Liquid Chromatographic Method for the Simultaneous Determination of Eprosartan and Hydrchlorothiazide in Tablets
}

\author{
T. SRINIVASU ${ }^{* 1}$, M. MATHRUSRI ANNAPURNA ${ }^{2}$ and T.G. CHANDRASHEKHAR ${ }^{3}$ \\ ${ }^{1}$ Department of Science and Technology, JNTU, Hyderabad, India \\ ${ }^{2}$ GITAM Institute of Pharmacy, GITAM University, Visakhapatnam, India \\ ${ }^{3}$ Ranbaxy Research Laboratories Ltd., Haryana, India \\ srinivasu.topalli@gmail.com
}

Received 31 January 2014 / Accepted 19 February 2014

\begin{abstract}
A validated stability-indicating high-performance liquid chromatographic method has been developed for the simultaneous determination of Eprosartan and hydrochlorothiazide in tablet dosage forms. Chromatographic separation was performed on HPLC system of waters Model 2997 using X Bridge Shield RP18 (150 x $3.0 \mathrm{~mm}$ i.d., $3.5 \mu \mathrm{m}$ particle size $)$ column with a mixture of $0.1 \%$ formic acid and acetonitrile as mobile phase with a flow rate of $0.8 \mathrm{~mL} / \mathrm{min}$ (gradient mode) with UV detection at $235 \mathrm{~nm}$. The combinationof drugs was subjected to stress conditions such as acidic, alkaline, oxidation photolytic and thermal degradations and the method was validated as per ICH guidelines.
\end{abstract}

Keywords: Eprosartan, Hydrochlorothiazide, RP-HPLC, Stability-indicating, ICH

\section{Introduction}

Eprosartan $^{1}$ (EPR) is an angiotensin II receptor antagonist used for the treatment of high blood pressure (Figure 1). It acts on the renin-angiotensin system in two ways to decrease total peripheral resistance. First, it blocks the binding of angiotensin II to AT1 receptors in vascular smooth muscle, causing vascular dilatation. Second, it inhibits sympathetic norepinephrine production, further reducing blood pressure.<smiles>CCCCc1ncc(CC(Cc2cccs2)C(=O)O)n1Cc1ccc(C(=O)O)cc1</smiles>

Figure 1. Chemical structure of Eprosartan (EPR)

Hydrochlorothiazide $^{2}$ (HCTZ) is a first line diuretic drug of the thiazide class (Figure 2). It acts by lowering blood pressure initially by increasing sodium and water excretion. This causes a decrease in extracellular volume, resulting in a decrease in cardiac output and renal blood flow. With long-term treatment, plasma volume approaches a normal value, 
but peripheral resistance decreases. The combination of EPR and hydrochlorothiazide can be effectively and safely used inpatients ${ }^{3}$.<smiles>NS(=O)(=O)c1cc2c(cc1Cl)NCNS2(=O)=O</smiles>

Figure 2. Chemical structures of hydrchlorothiazide (HCTZ)

Literature survey reveals that Eprosartan was determined by ultraviolet spectrophotometry ${ }^{4}$ and high-performance liquid chromatography ${ }^{5}$ in pharmaceutical preparations. Several analytical methods have been published for the determination of Hydrchlorothiazide in tablet susingflowinjection ${ }^{6}$, spectrophotometric $^{7-9}$, densitometric ${ }^{10}$, HPLC $^{7-13}$, electrophoretic ${ }^{14-15}$ andpolarographic ${ }^{16}$ methods. The simultaneous determination of EPR and HCTZ was studied by HPTLC ${ }^{17}$, HPLC and derivative spectrophotmetry ${ }^{18}$. In the present study the authors have developed a simple, robust, precise and accurate RP-HPLC method has been developed for the simultaneous determination of hydrochlorothiazide and Eprosartan and validated as per ICH guidelines ${ }^{19-20}$.

\section{Instrumentation and chromatographic conditions}

Liquid chromatographic separation was achieved by using a waters X Bridge shield RP-18 $(150 \mathrm{~mm} \times 3.0 \mathrm{~mm}, 3.5 \mu \mathrm{m})$ column and waters HPLC Model 2997 with Empower2 software and photodiode array detector, maintained at $45{ }^{\circ} \mathrm{C}$. Gradient mode elution was performed using Acetonitrile and $0.1 \% \mathrm{v} / \mathrm{v}$ formic acid. The overall run time was $20 \mathrm{~min}$. and the flow rate of the mobile phase was $0.8 \mathrm{~mL} / \mathrm{min}$. The wavelength of the PDA detector was set at $235 \mathrm{~nm} .5 \mu \mathrm{L}$ of sample was injected into the HPLC system.

\section{Experimental}

Eprosartan standard (purity 99.4\%) and was obtainedfrom Solvay, India) and hydrchlorothiazide standard (purity 99.8\%) and was obtainedfrom Ranbaxy, India). Acetonitrile (HPLC grade), sodium hydroxide (Merck) and hydrochloric acid (Merck) and Hydrogen peroxide (Merck) and all other chemicals were of analytical grade.

The combination of Eprosartan and hydrochlorothiazide is available with brand names TEVENTEN HCT (Lupin) and TEVETEN PLUS (Torrent) (Label claim: $600 \mathrm{mg}$ (EPR) and $12.5 \mathrm{mg}$ (HCTZ).

\section{Preparation of $0.1 \%$ formic acid solution}

$1.0 \mathrm{~mL}$ of Formic acid was added to a $1000 \mathrm{~mL}$ volumetric flask and made up to volume with HPLC grade water.

\section{Preparation of stock solutions}

Hydrochlorothiazide $(2500 \mu \mathrm{g} / \mathrm{mL})$ and Eprosartan $(2400 \mu \mathrm{g} / \mathrm{mL})$ stock solutions were prepared by accurately transferring $125 \mathrm{mg}$ of HCTZ and $120 \mathrm{mg}$ of EPR in a $50 \mathrm{~mL}$ volumetric flask with diluent. Standard solutions were prepared by further diluting $5 \mathrm{~mL}$ of the stock solution to $50 \mathrm{~mL}$ with diluent.

Working standard solutions were prepared on daily basis from the stock solutions by dilution with mobile phase and the solutions were filtered through $0.45 \mu \mathrm{m}$ membrane filter prior to injection. 


\section{Method Validation}

\section{Linearity}

A series of solutions were prepared from the stock solutions of Hydrochlorothiazide $(1.0-300.0 \mu \mathrm{g} / \mathrm{mL})$ and Eprosartan $(19.2-750.3 \mu \mathrm{g} / \mathrm{mL})$ using the diluents and $5 \mu \mathrm{L}$ of each solution was injected in to the HPLC system and the peak area of the chromatogram was noted. A graph was drawn by taking the concentration of the drug solutions on the $\mathrm{x}$-axis and the corresponding peak area on the y-axis.

\section{Precision}

The intra-day and inter-day precision of the assay method was evaluated by carrying out six independent assays of test samples of Eprosartan $(540 \mu \mathrm{g} / \mathrm{mL})$ and hydrochlorothiazide $(250 \mu \mathrm{g} / \mathrm{mL})$ against a qualified reference standard and the \% RSD was calculated.

\section{Accuracy}

The accuracy of the assay method was evaluated in triplicate by spiking individual standard solutions at three concentration levels $(80,100$ and 120\%) and the percentage recoveries were calculated. Standard addition and recovery experiments were conducted to determine the accuracy of the method for the quantification of hydrochlorothiazide and Eprosartan respectively and the \% RSD was calculated.

\section{Robustness}

The robustness of the assay method was established by introducing small deliberate changes in the HPLC conditions which included flow rate $(0.72$ and $0.88 \mathrm{~mL} / \mathrm{min})$, percentage of acetonitrile in the mobile phase (absolute $\pm 2 \%$ composition) and column oven temperature $\left( \pm 5^{\circ} \mathrm{C}\right)$.

\section{Limit of quantification (LOQ) and limit of detection (LOD)}

The LOQ and LOD were determined as described in International Conference on Harmonization guidelines Q2 (R1).

\section{Analysis of commercial formulations}

Twenty tablets of two different brands containing Eprosartan and Hydrochlorothiazide were procured from the local medical store and analyzed as per the method and the percentage recovery was calculated from the linear regression equation using the mean peak area obtained from the respective chromatograms.

\section{Forced degradation studies}

Forced degradation studies ${ }^{15}$ were intended to ensure the effective separation of Eprosartan and hydrochlorothiazide and their degradation peaks. Forced degradation studies were performed with the combined formulation containing $12000 \mu \mathrm{g} / \mathrm{mL}$ of Eprosartan and $250 \mu \mathrm{g} / \mathrm{mL}$ of Hydrochlorothiazide and diluted as per the requirement before injecting in to the system.

\section{Acidic and alkaline degradation studies}

Acid decomposition was carried out by refluxing the combined formulation of Eprosartan and of hydrochlorothiazide solution with $1 \mathrm{~N} \mathrm{HCl}$ in a thermostat maintained at $80^{\circ} \mathrm{C}$ for $2 \mathrm{~h}$ and then the stressed sample was cooled, neutralized and diluted with mobile phase. Similarly alkaline degradation was conducted using $1 \mathrm{~N} \mathrm{NaOH}$ for $2 \mathrm{~h}$ in thermostat maintained at $80{ }^{\circ} \mathrm{C}$. After cooling the solution was neutralized and diluted with mobile phase as per the requirement and $5 \mu \mathrm{L}$ was injected in to the system. 


\section{Oxidation degradation studies}

Solutions for oxidative stress studies were prepared by refluxing the combined formulation of Eprosartan and of hydrochlorothiazide solution with $1 \% \mathrm{H}_{2} \mathrm{O}_{2}$ and after refluxation for $2 \mathrm{~h}$ at 80 ${ }^{\circ} \mathrm{C}$ in the thermostat the drug solution was cooled and diluted accordingly with the mobile phase.

\section{Thermal degradation studies}

For thermal stress testing, the combined formulation of Eprosartan and of hydrochlorothiazide was heated in an oven at $105^{\circ} \mathrm{C}$ for $72 \mathrm{~h}$, cooled and then injected in to the HPLC system.

\section{Photolytic degradation studies}

The combined formulation of Eprosartan and of hydrochlorothiazide was kept in photolytic chamber at 1289069 Lux Hours and 1024.2.66 Watt-Hour $/ \mathrm{m}^{2}$ and analyzed.

\section{Humidity degradation}

The combined formulation of Eprosartan and of Hydrochlorothiazide was kept in desiccator at $25{ }^{\circ} \mathrm{C}, 95 \% \mathrm{RH}$ for $120 \mathrm{~h}$. The sample solutions were prepared with the stressed sample with diluent as per the requirement and filtered through $0.45 \mu \mathrm{m}$ filter. $5 \mu \mathrm{L}$ of this solution was injected into the HPLC system and analysed.

\section{Results and Discussion}

A reversed-phase liquid chromatographic technique was developed to quantitate eprosartan and hydrochlorothiazide in pharmaceutical dosage forms (Tablets) and validated as per ICH guidelines. No stability indicating liquid chromatographic method has not yet been reported earlier.

\section{Method development and optimization}

For selection of column, a spiked sample of Eprosartan and hydrochlorothiazide was prepared and injected into HPLC system on different columns. The required system suitability criterion was obtained using X Bridge Shield RP-18 $(150 \times 3.0 \mathrm{~mm}), 3.5 \mu \mathrm{m}$ column (Table 1). The optimized chromatographic conditions were shown in Table 2 and the chromatogram obtained for the blank was shown in Figure 3.

Table 1. Selection of column in method optimization

\begin{tabular}{|c|c|}
\hline Column conditions & Remark \\
\hline Luna C-18(2) (150x4.6 mm), $5 \mu \mathrm{m}$ & HCTZ peak eluting in the void. \\
\hline $\begin{array}{l}\text { YMC pro pack C-18 }(150 \times 4.6 \mathrm{~mm}) \\
5 \mu \mathrm{m}, 45^{\circ} \mathrm{C}\end{array}$ & HCTZ peak eluting in the void. \\
\hline Kromasil C-18 (150x $4.6 \mathrm{~mm}), 3.5 \mu \mathrm{m}$ & HCTZ peak eluting in the void. \\
\hline Flow rate $1.1 \mathrm{~mL} / \mathrm{min}$, Gradient2 & Eprosartan peak co-eluting with the blank peak. \\
\hline X Bridge RP-18 (150x4.6 mm) $3.5 \mu \mathrm{m}$ & Eprosartan peak co-eluting with the blank peak \\
\hline X Bridge Shield RP-18 (150x3.0 mm), $3.5 \mu \mathrm{m}$ & Eprosartan peak separated from blank peak \\
\hline $\begin{array}{l}\text { X Bridge Shield RP-18 }(150 \times 3.0 \mathrm{~mm}) \text {, } \\
3.5 \mu \mathrm{m} \text {, different gradient }\end{array}$ & Eprosartan peak separated from blank peak \\
\hline
\end{tabular}

\section{Method validation}

The typical chromatogram of hydrochlorothiazide and Eprosartan was shown in Figure 4 and the corresponding peak purity plots were shown in Figure 5. Beer-Lambert's law was obeyed over the concentration range $1-300 \mu \mathrm{g} / \mathrm{mL}$ for hydrochlorothiazide and 19.2-750.3 $\mu \mathrm{g} / \mathrm{mL}$ for Eprosartan respectively (Table 3) with regression equations $\mathrm{y}=5980.5 \mathrm{x}+535.64$ $\left(\mathrm{R}^{2}=0.9999\right)$ (Figure $6 \mathrm{~A}$ ) and $\mathrm{y}=8199.2 \mathrm{x}+565.86\left(\mathrm{R}^{2}=0.9998\right)$ (Figure $\left.6 \mathrm{~B}\right)$ respectively. 
Table 2. Optimized chromatographic conditions

\begin{tabular}{llcc}
\hline Column & \multicolumn{1}{l}{ X Bridge Shield RP18 $(150 \times 3.0) \mathrm{mm}, 3.5 \mu \mathrm{m}$} \\
\hline Injection volume & $: 5 \mu \mathrm{L}$ & & \\
Mobile phase & $: 0.1 \%$ Formic acid in water and Acetonitrile Gradient mode \\
Flow rate & $: 0.8 \mathrm{~mL} / \mathrm{min}$ & & \\
\cline { 2 - 3 } & Time, $\mathrm{min}$ & $\%(0.1 \%$ formic acid $)$ & $\%$ Acetonitrile $(\% \mathrm{v} / \mathrm{v})$ \\
& 0 & 90 & 10 \\
2 & 90 & 10 \\
4 & 80 & 20 \\
& 16 & 10 & 90 \\
& 17 & 90 & 10 \\
& 17.5 & 90 & 10 \\
\hline
\end{tabular}

\begin{tabular}{ll}
\hline Detection wavelength & $: 235 \mathrm{~nm}$ \\
Column oven Temp. & $: 45^{\circ} \mathrm{C}$ \\
\hline
\end{tabular}

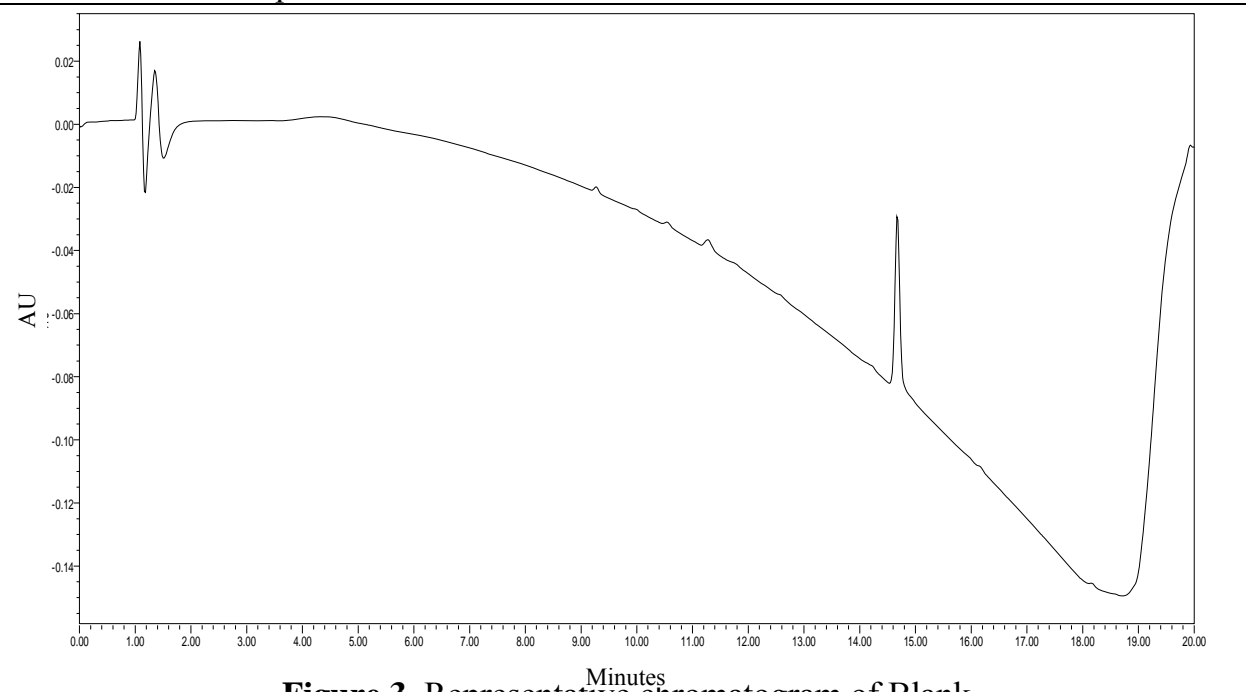

Figure 3. Representative chromatogram of Blank

Table 3. Linearity of Hydrochlorothiazide and Eprosartan Hydrochlorothiazide Eprosartan

\begin{tabular}{cccc}
\hline Conc. $\mu \mathrm{g} / \mathrm{mL}$ & *Mean peak area & Conc. $\mu \mathrm{g} / \mathrm{mL}$ & *Mean peak area \\
\hline 1.001 & 8946 & 19.208 & 156894 \\
10.010 & 97196 & 24.010 & 201649 \\
20.020 & 195989 & 48.021 & 401246 \\
30.030 & 294899 & 144.062 & 1180596 \\
60.060 & 589665 & 240.104 & 1960469 \\
100.100 & 983495 & 420.182 & 3446658 \\
137.638 & 1362983 & 480.208 & 3934697 \\
175.175 & 1749458 & 540.234 & 4406879 \\
200.200 & 1966459 & 600.260 & 4895216 \\
250.250 & 2458536 & 660.286 & 5498466 \\
300.300 & 2960249 & 750.325 & 6120964 \\
\hline
\end{tabular}

* Mean of three replicates 
The LOQ and LOD for Eprosartan were found to be $2.305 \mu \mathrm{g} / \mathrm{mL}$ and $0.761 \mu \mathrm{g} / \mathrm{mL}$ respectively whereas the LOQ and LOD for Hydrochlorothiazide were found to be $0.921 \mu \mathrm{g} / \mathrm{mL}$ and $0.304 \mu \mathrm{g} / \mathrm{mL}$ respectively.

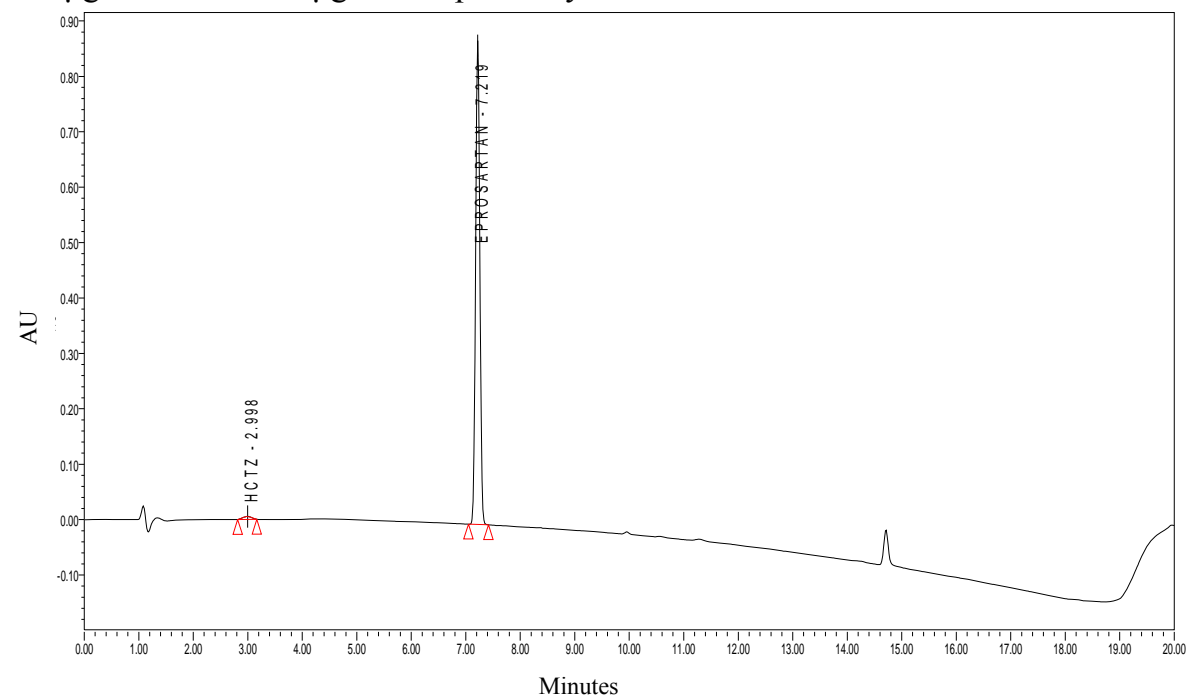

Figure 4. Typical chromatogram of hydrochlorothiazide $(5 \mu \mathrm{g} / \mathrm{mL})$ and Eprosartan $(240 \mu \mathrm{g} / \mathrm{mL})$
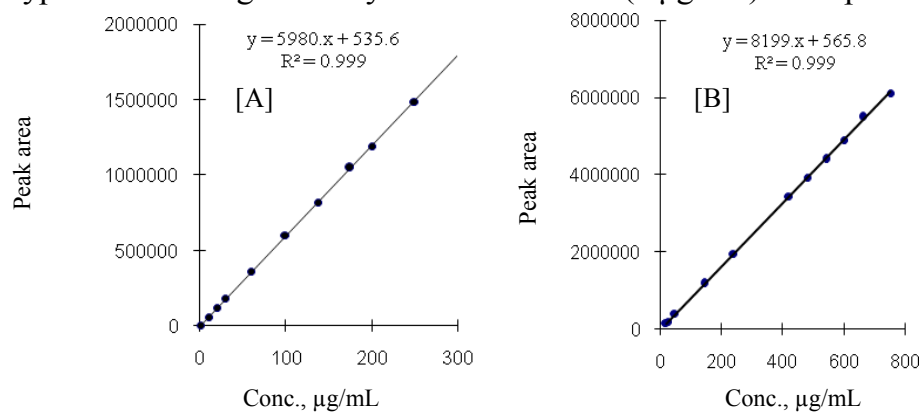

Figure 5. Calibration curves of Eprosartan [A] and Hydrochlorothiazide [B]

The \% RSD for intra-day and inter-day precision study was found to be $0.14-0.36$ and $0.18-0.33$ for EPR (Table 5) where as the RSD for intra-day and inter-day precision study for HCTZ was found to be $0.16-0.34$ and $0.15-0.34$ (Table 4) respectively which is less than $2 \%$ indicating that the method is precise.

Table 4. Precision study of Hydrochlorothiazide

\begin{tabular}{cccc}
\hline \multicolumn{4}{c}{ Hydrochlorothiazide (HCTZ) } \\
\hline Intra-day & \multicolumn{3}{c}{ Inter-day } \\
\hline *Mean peak area \pm SD & RSD \% & *Mean peak area \pm SD & RSD \% \\
\hline $2499456 \pm 3999.130$ & 0.16 & $2498745 \pm 3997.992$ & 0.16 \\
$2516423 \pm 5536.131$ & 0.22 & $2503369 \pm 3755.054$ & 0.15 \\
$2498456 \pm 8494.750$ & 0.34 & $2488942 \pm 8462.403$ & 0.34 \\
$2498997 \pm 4498.195$ & 0.18 & $2498512 \pm 6246.280$ & 0.25 \\
$2516846 \pm 7298.853$ & 0.29 & $2496349 \pm 8237.952$ & 0.33 \\
$2509781 \pm 6525.431$ & 0.26 & $2489994 \pm 4730.989$ & 0.19 \\
\hline
\end{tabular}

*Mean of three replicates 
The \% RSD accuracy study was found to be $0.25-1.43$ for EPR and $0.27-0.36$ for HCTZ (Table 6) respectively. The \% RSD for robustness study was found to be $0.13-0.78$ for EPR and 0.15-0.54 for HCTZ (Table 7) respectively.

Table 5. Precision study of Eprosartan

\begin{tabular}{cccc}
\hline Intra-day & \multicolumn{3}{c}{ Inter-day } \\
\hline *Mean peak area \pm SD & RSD $\%$ & $*$ Mean peak area \pm SD & RSD \% \\
\hline $4260552 \pm 9373.214$ & 0.22 & $4365664 \pm 13970.125$ & 0.32 \\
$4261864 \pm 15342.710$ & 0.36 & $4264977 \pm 8956.452$ & 0.21 \\
$4256489 \pm 5959.085$ & 0.14 & $4263498 \pm 14069.543$ & 0.33 \\
$4259974 \pm 6815.958$ & 0.16 & $4264784 \pm 10661.960$ & 0.25 \\
$4260646 \pm 13634.067$ & 0.32 & $4268264 \pm 7682.875$ & 0.18 \\
$4261169 \pm 14061.858$ & 0.33 & $4359874 \pm 9591.723$ & 0.22 \\
\hline
\end{tabular}

* Mean of three replicates

Table 6. Accuracy study of Eprosartan and Hydrochlorothiazide

\begin{tabular}{cccc}
\hline Drug & Level & \% Recovery* & \%RSD \\
\hline \multirow{3}{*}{ Eprosartan } & $80 \%$ & 100.12 & 1.43 \\
& $100 \%$ & 100.19 & 1.00 \\
& $120 \%$ & 99.75 & 0.25 \\
\hline \multirow{3}{*}{ Hydrochlorothiazide } & $80 \%$ & 99.84 & 0.27 \\
& $100 \%$ & 99.33 & 0.36 \\
& $120 \%$ & 99.78 & 0.32 \\
\hline
\end{tabular}

*Mean of three replicates

Table 7. Robustness study of eprosartan and hydrochlorothiazide

\begin{tabular}{|c|c|c|c|c|c|c|c|}
\hline \multirow{3}{*}{ Parameter } & \multirow{3}{*}{ Condition } & \multicolumn{6}{|c|}{ System suitability } \\
\hline & & \multicolumn{3}{|c|}{ Hydrochlorothiazide } & \multicolumn{3}{|c|}{ Eprosartan } \\
\hline & & $\begin{array}{l}\text { Tailing } \\
\text { factor }\end{array}$ & $\begin{array}{c}\text { Theoretical } \\
\text { plates }\end{array}$ & $\begin{array}{c}\text { RSD } \\
\%\end{array}$ & $\begin{array}{l}\text { Tailing } \\
\text { factor }\end{array}$ & $\begin{array}{c}\text { Theoretical } \\
\text { plates }\end{array}$ & $\begin{array}{c}\text { RSD } \\
\%\end{array}$ \\
\hline Flow rate & 0.72 & 1.12 & 2986 & 0.19 & 1.11 & 89456 & 0.13 \\
\hline$( \pm 0.08 \mathrm{~mL} / \mathrm{min})$ & 0.88 & 1.08 & 3085 & 0.54 & 1.04 & 90456 & 0.52 \\
\hline $\mathrm{ACN}$ : formic & $58: 42$ & 1.13 & 2688 & 0.19 & 1.10 & 96415 & 0.16 \\
\hline $\operatorname{acid}( \pm 2 \%, \mathrm{v} / \mathrm{v})$ & $62: 38$ & 1.09 & 2860 & 0.54 & 1.09 & 98954 & 0.36 \\
\hline Column oven & $40^{\circ} \mathrm{C}$ & 1.10 & 2895 & 0.15 & 1.11 & 78056 & 0.44 \\
\hline $\begin{array}{c}\text { temperature } \\
\left( \pm 5^{\circ} \mathrm{C}\right)\end{array}$ & $50^{\circ} \mathrm{C}$ & 1.10 & 3046 & 0.36 & 1.06 & 90146 & 0.78 \\
\hline
\end{tabular}

\section{Analysis of commercial formulations}

The proposed method was applied for the determination of Hydrochlorothiazide and Eprosartan tablets and the percentage recovery was found to be 99.40-99.44 and 99.23-99.44 respectively (Table 8) and no interference was observed with the excipients.

Table 8. Analysis of commercial formulation (Tablets)

\begin{tabular}{ccccccc}
\hline \multirow{2}{*}{ Brand name } & \multicolumn{2}{c}{ Labeled amount $\mathrm{mg}$} & \multicolumn{2}{c}{ Amount found mg } & \multicolumn{2}{c}{ Recovery, \% } \\
\cline { 2 - 7 } & EPR & HCTZ & EPR & HCTZ & EPR & HCTZ \\
\hline Brand I & 600 & 12.5 & 595.76 & 12.43 & 99.23 & 99.44 \\
Brand II & 600 & 25 & 596.64 & 24.85 & 99.44 & 99.40 \\
\hline
\end{tabular}




\section{Forced degradation studies/specificity}

During acidic degradation, the chromatogram shows peaks at $2.854 \mathrm{~min}$ and $7.281 \mathrm{~min}$ indicating the elution of Hydrochlorothiazide and Eprosartan respectively (Figure 6). On acidic degradation HCTZ has not at all undergone degradation where as $1.04 \%$ of decomposition was observed with EPR. The purity angle (0.083) was less than the purity threshold (1.030) indicating that EPR does not interference with degradants and similarly the purity angle (0.349) was less than the purity threshold (1.051) for HCTZ. Therefore it can be concluded that the method is specific and selective.

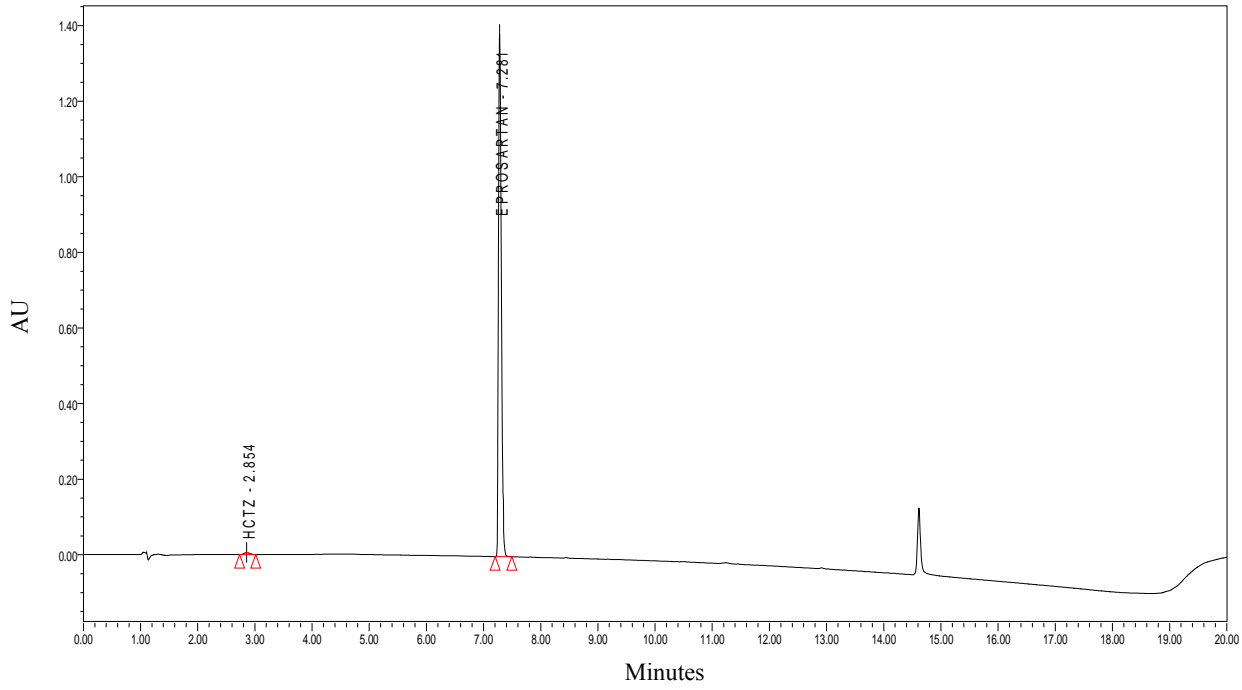

Figure 6. Typical chromatogram of Hydrochlorothiazide $(5 \mu \mathrm{g} / \mathrm{mL})$ and Eprosartan $(240 \mu \mathrm{g} / \mathrm{mL})$ (Acidic degradation)

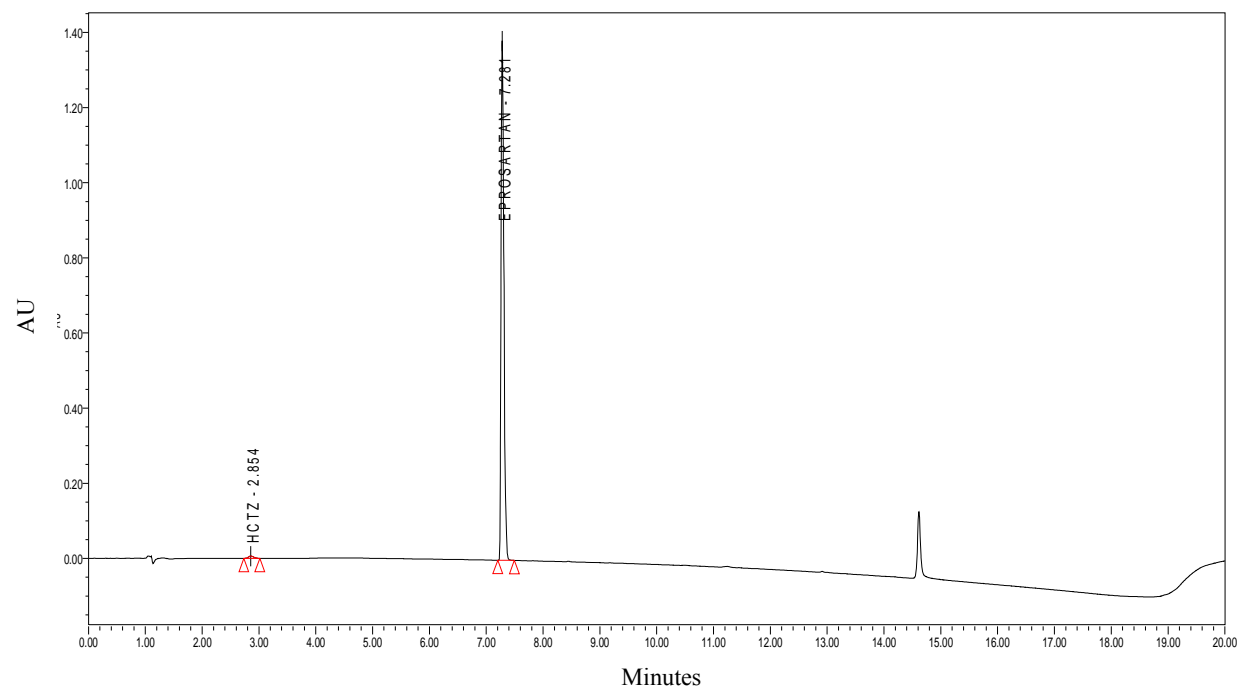

Figure 7. Typical chromatogram of Hydrochlorothiazide $(5 \mu \mathrm{g} / \mathrm{mL})$ and Eprosartan $(240 \mu \mathrm{g} / \mathrm{mL})$ (Acidic degradation) 
During alkaline degradation, the chromatogram shows peaks at $2.858 \mathrm{~min}$ and 7.284 min indicating the elution of Hydrochlorothiazide and Eprosartan respectively. $1.17 \%$ of EPR has undergone alkaline degradation and only $0.66 \%$ of HCTZ was decomposed (Figure 7). The purity angle (0.079) for EPR was less than the purity threshold (1.030) indicating that no interference of degradants and similarly the purity angle (0.0678) was less than the purity threshold (2.125) for HCTZ.

During oxidative degradation, the chromatogram shows peaks at $2.856 \mathrm{~min}$ and 7.290 min indicating the elution of Hydrochlorothiazide and Eprosartan respectively. During oxidative degradation about $3.60 \%$ of EPR and $3.52 \%$ of HCTZ have undergone decomposition without degradants (Figure 8$)$. The purity angle $(0.080)$ was less than the purity threshold (1.030) indicating that EPR peak was well separated and similarly the purity angle (0.762) was less than the purity threshold (2.023) for HCTZ.

During thermal degradation the chromatogram shows peaks at $2.867 \mathrm{~min}$ and $7.326 \mathrm{~min}$ indicating the elution of Hydrochlorothiazide and Eprosartan respectively. HCTZ has undergone $1.22 \%$ degradation where as $2.65 \%$ of decomposition was observed with EPR (Figure 9). The purity angle (0.107) was less than the purity threshold (1.079) indicating that EPR indicating that there is no interference. Similarly the purity angle $(0.045)$ was less than the purity threshold (1.060) for HCTZ.

During photolytic degradation the chromatogram shows peaks at $2.868 \mathrm{~min}$ and $7.332 \mathrm{~min}$ indicating the elution of Hydrochlorothiazide and Eprosartan respectively (Figure 10). HCTZ has not at all undergone degradation where as $2.01 \%$ of decomposition was observed with EPR. The purity angle $(0.110)$ was less than the purity threshold (1.082) indicating that EPR indicating that there is no interference and similarly the purity angle $(0.048)$ was less than the purity threshold (1.061) for HCTZ. Therefore it can be concluded that the method is specific and selective. As no new degradants were observed mass spectral analysis was not performed.

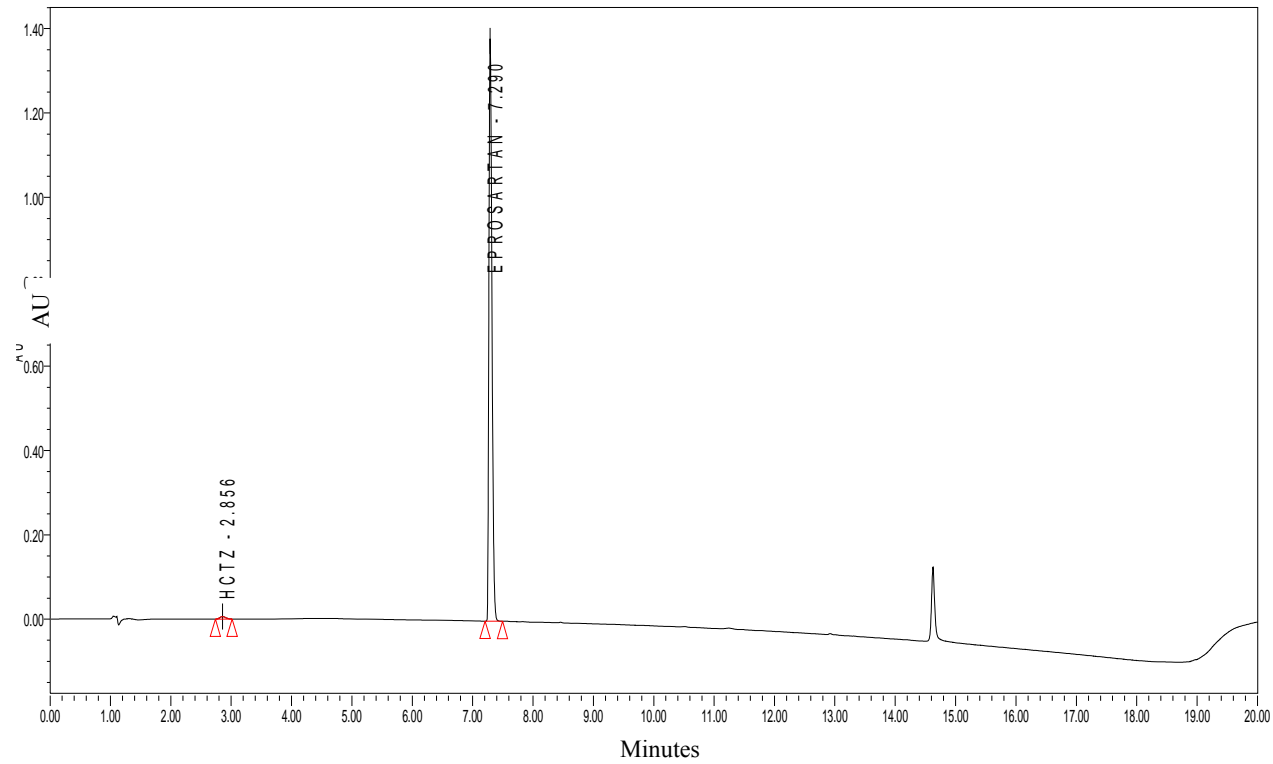

Figure 8. Typical chromatogram of Hydrochlorothiazide $(5 \mu \mathrm{g} / \mathrm{mL})$ and Eprosartan $(240$ $\mu \mathrm{g} / \mathrm{mL}$ ) (Oxidative degradation) 
On humidity degradation the chromatogram shows peaks at $2.864 \mathrm{~min}$ and $7.326 \mathrm{~min}$ indicating the elution of Hydrochlorothiazide and Eprosartan respectively (Figure 11). On humidity exposure to $95 \% \mathrm{RH}$ at $25^{\circ} \mathrm{C}$ for 120 hours, $\mathrm{HCTZ}$ has not at all undergone degradation where as $1.27 \%$ of decomposition was observed with EPR. The purity angle (0.107) was less than the purity threshold (1.070) indicating that EPR indicating that there is no interference and similarly the purity angle $(0.048)$ was less than the purity threshold (1.063) for HCTZ. Therefore it can be concluded that the method is specific and selective.

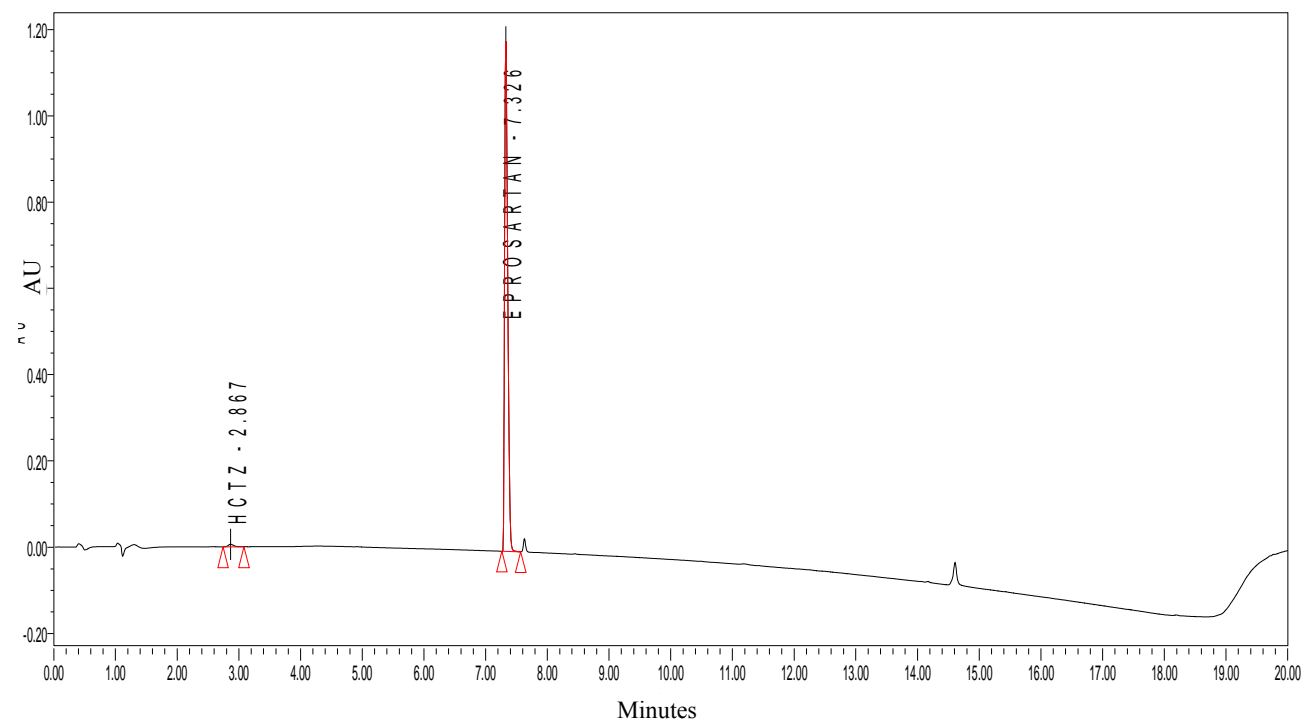

Figure 9. Typical Representative chromatogram of Hydrochlorothiazide $(5 \mu \mathrm{g} / \mathrm{mL})$ and Eprosartan $(240 \mu \mathrm{g} / \mathrm{mL})$ (Thermal degradation)

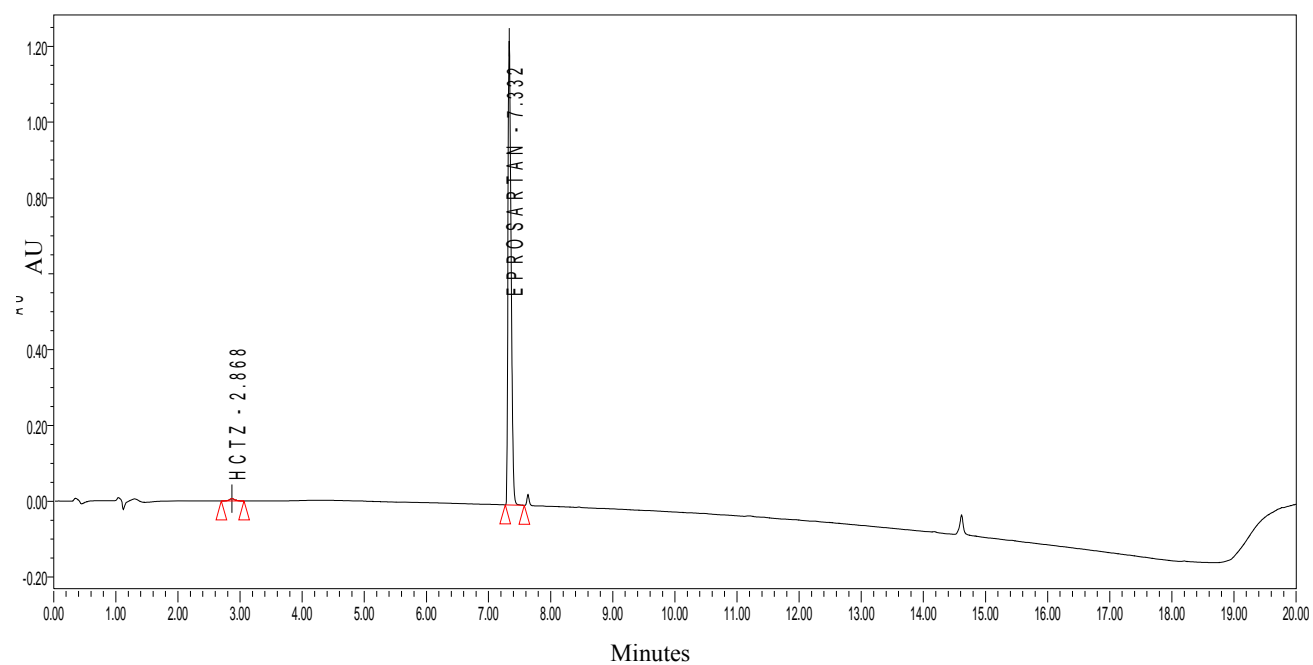

Figure 10. Typical chromatogram of Hydrochlorothiazide $(5 \mu \mathrm{g} / \mathrm{mL})$ and Eprosartan $(240$ $\mu \mathrm{g} / \mathrm{mL}$ ) (Photolytic degradation) 


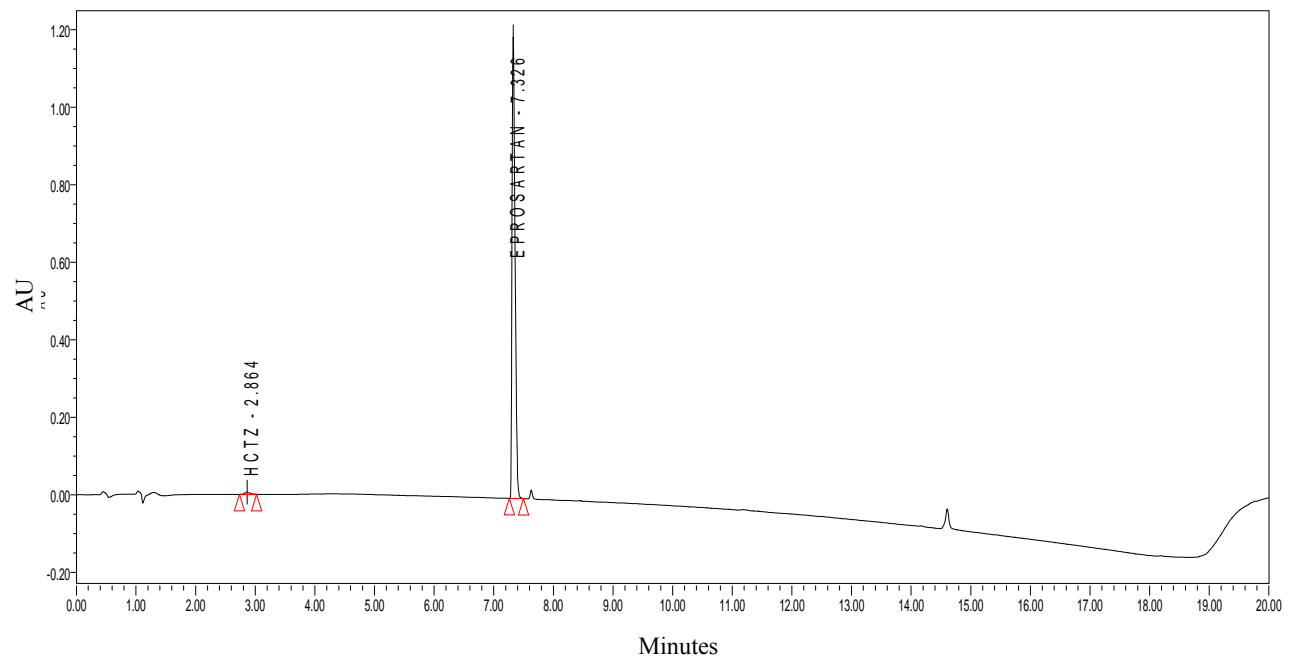

Figure 11. Typical chromatogram of Hydrochlorothiazide $(5 \mu \mathrm{g} / \mathrm{mL})$ and Eprosartan $(240$ $\mu \mathrm{g} / \mathrm{mL}$ ) (Humidity degradation)

The system suitability tests were performed to ensure that the complete testing system was suitable for the intended application. The tailing factor was 1.11 (HCTZ) and 1.04 (EPR) which is $<1.5-2$ or $<2$ and the theoretical plates were found to be 3082 (HCTZ) and 97156 (EPR) which is $>2000$. A brief summary of forced degradation studies of Eprosartan and Hydrochlorothiazide was given in Table 9.

Table 9. Forced degradation studies of Hydrochlorothiazide and Eprosartan

\begin{tabular}{|c|c|c|c|c|c|c|c|c|c|c|}
\hline \multirow[t]{2}{*}{$\begin{array}{c}\text { Stress } \\
\text { conditions }\end{array}$} & \multicolumn{2}{|c|}{ Mean peak area } & \multicolumn{2}{|c|}{$\begin{array}{c}\text { Drug } \\
\text { recovered } \\
\% \\
\end{array}$} & \multicolumn{2}{|c|}{$\begin{array}{c}\text { Drug } \\
\text { decomposed } \\
\% \\
\end{array}$} & \multicolumn{2}{|c|}{ Purity angle } & \multicolumn{2}{|c|}{$\begin{array}{l}\text { Purity } \\
\text { threshold }\end{array}$} \\
\hline & HCTZ & EPR & HCTZ & EPR & HCTZ & EPR & HCTZ & EPR & HCTZ & EPR \\
\hline Untreated & 2468469 & 1966496 & 100 & 100 & - & 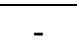 & 0.532 & 0.790 & 1.851 & 1.029 \\
\hline $\begin{array}{c}\text { Acidic } \\
\text { degradation }\end{array}$ & 2471650 & 1946123 & 100.13 & 98.96 & - & 1.04 & 0.349 & 0.083 & 1.051 & 1.030 \\
\hline $\begin{array}{c}\text { Alkaline } \\
\text { degradation }\end{array}$ & 2452295 & 1943454 & 99.34 & 98.83 & 0.66 & 1.17 & 78 & 0.079 & 25 & 1.030 \\
\hline $\begin{array}{l}\text { Oxidative } \\
\text { degradation }\end{array}$ & 2381563 & 1895769 & 96.48 & 96.40 & 3.52 & 3.60 & 0.762 & 0.080 & 2.023 & 1.030 \\
\hline $\begin{array}{l}\text { Thermal } \\
\text { degradation }\end{array}$ & 2438272 & 1914341 & 98.78 & 97.35 & 1.22 & 2.65 & 0.045 & 0.107 & 1.060 & 1.079 \\
\hline $\begin{array}{l}\text { Photolytic } \\
\text { degradation }\end{array}$ & 2480377 & 1926923 & 100.48 & 97.99 & - & 2.01 & 0.048 & 0.110 & 1.061 & 1.082 \\
\hline $\begin{array}{l}\text { Humidity } \\
\text { degradation }\end{array}$ & 2466101 & 1941465 & 99.90 & 98.73 & 0.10 & 1.27 & 0.048 & 0.107 & 1.063 & 1.070 \\
\hline
\end{tabular}

\section{Conclusion}

The present developed RP-HPLC method was stability indicating simple, specific, precise, accurate and robust. It can be applied for the determination of Eprosartan and Hydrochlorothiazide in pharmaceutical dosage forms as well as for pharmacokinetic studies. 


\section{Acknowledgement}

We are grateful to Ranbaxy Laboratories, India for providing the gift samples of drugs.

\section{References}

1. Budavari S, (Ed.), The Merck Index, AnEncyclopediaofchemicals, drugs and biologicals, $13^{\text {th }}$ Ed., Whitehouse Station, N J, Merck Research Laboratories Division of Merck and Co., Inc., 2001.

2. Budavari S, (Ed.), The Merck Index, $14^{\text {th }}$ Ed., Whitehouse Station, NJ, Merck Research Laboratories Division of Merck and Co., Inc. 2006.

3. Bohm M and Sachse A, Drug Safety, 2002, 25(8), 599-611; DOI:10.2165/00002018-200225080-00005

4. Kamila M M, Mondal N and Ghosh L K, Ind J Chem Tech., 2008, 15(2), 194-196.

5. Patel H U, Suhagia B N and Patel C N, J AOAC Int., 2010, 93(6), 1862-1867.

6. Ouyang J, Baeyens W R G, Delanghe J, Vander Weken G and Calokerinos A C, Talanta, 1998, 46(5), 961-968; DOI:10.1016/S0039-9140(97)00352-4

7. Bigley F P, Grob R L and Brenner G S, Anal Chim Acta, 1986, 181, 241-244;

DOI:10.1016/S0003-2670(00)85240-X

8. Saglik S, Sagirli O, Atmaca S and Ersoy L, Anal Chim Acta, 2001, 427(2), 253-257; DOI:10.1016/S0003-2670(00)01201-0

9. Ulvi V and Keski-Hynnila H, J Pharm Biomed Anal., 1994, 12(7), 917-922; DOI:10.1016/0731-7085(94)E0014-R

10. ElGindy A, Ashour A, Laila A F and Marwan M S, J Pharm Biomed Anal., 2001, 25(2), 171-179; DOI:10.1016/S0731-7085(00)00480-5

11. Hertzog D L, McCafferty J F, Fang X, Tyrrell R J and Reed R A, J Pharm Biomed Anal, 2002, 30(3), 747-760; DOI:10.1016/S0731-7085(02)00385-0

12. Erk N, J Pharm Biomed Anal., 2001, 24(4), 603-611; DOI:10.1016/S0731-7085(00)00434-9

13. Carlucci G, Palumbo G, Mazzeo P and Quaglia M G, J Pharm Biomed Anal., 2000, 23(1), 185-189; DOI:10.1016/S0731-7085(00)00268-5

14. Luz Luis M, Corujedo S, Blanco D, Fraga J M G, Jimenez A I, Jimenez F and Arias J J, Talanta, 2002, 57(2), 223-231; DOI:10.1016/S0039-9140(02)00018-8

15. Hillaert S, De Grauwe K and Vanden Bossche W, J Chromatogr A, 2001, 924(1-2), 439-449; DOI:10.1016/S0021-9673(01)00714-2

16. Martın M E, Hernandez O M, Jimenez A I, Arias J J and Jimenez F, Anal Chim Acta, 1999, 381(2-3), 247-254; DOI:10.1016/S0003-2670(98)00732-6

17. Patel H U, Suhagia B N and Patel C N, Acta Chromatogr., 2009, 21(2), 319-326.

18. Fatma Hacioglu and Armagan Onal, J Chromatogr Sci., 2012, 50(8), 688-693; DOI:10.1093/chromsci/bms037

19. ICH Validation of analytical procedures: Text and methodology, Q2 (R1), International Conference on Harmonization, 2005.

20. Stability Testing of New Drug Substances and Products, ICH Harmonized Tripartite Guidelines, 1995. 